\title{
Using SHRIMP zircon dating to unravel tectonothermal events in arc environments. The early Palaeozoic arc of NW Iberia revisited
}

\author{
Jacobo Abati, ${ }^{1}$ Pedro Castiñeiras, ${ }^{2}$ Ricardo Arenas, ${ }^{1}$ Javier Fernández-Suárez, ${ }^{1}$ Juan Gómez Barreiro ${ }^{3}$ \\ and Joseph L. Wooden ${ }^{4}$ \\ ${ }^{1}$ Departamento de Petrología y Geoquímica, Universidad Complutense, 2840 Madrid, Spain; ${ }^{2}$ Department of Geological Sciences, University \\ of Colorado, Boulder, CO 80309, USA; ${ }^{3}$ Department of Earth and Planetary Science, University of California, Berkeley, CA 9420-4767, \\ USA; ${ }^{4}$ USGS at Menlo Park, 345 Middlefield Road, Menlo Park, CA 9425, USA
}

\begin{abstract}
Dating of zircon cores and rims from granulites developed in a shear zone provides insights into the complex relationship between magmatism and metamorphism in the deep roots of arc environments. The granulites belong to the uppermost allochthonous terrane of the NW Iberian Massif, which forms part of a Cambro-Ordovician magmatic arc developed in the peri-Gondwanan realm. The obtained zircon ages confirm that voluminous calc-alkaline magmatism peaked around $500 \mathrm{Ma}$ and was shortly followed by granulite facies metamorphism accompanied by deformation at c. $480 \mathrm{Ma}$, giving a time framework for crustal heating, regional metamorphism, defor-
\end{abstract}

mation and partial melting, the main processes that control the tectonothermal evolution of arc systems. Traces of this arc can be discontinuously followed in different massifs throughout the European Variscan Belt, and we propose that the uppermost allochthonous units of the NW Iberian Massif, together with the related terranes in Europe, constitute an independent and coherent terrane that drifted away from northern Gondwana prior to the Variscan collisional orogenesis.

\section{Introduction}

The tectonothermal evolution of magmatic arcs is a key issue to understand the evolution of continental crust through time, as they are arguably the main geological setting for its formation and growth (e.g. Yoshino and Takamoto, 2004; Holbrook et al., 1999). Many recent studies show that high-temperature metamorphism and magmatism in this enviromnent are closely related in space and time, showing a complex interplay where several thermal and/or deformational events can be developed in short time spans and show feedback relationships (Corona-Chávez et al., 2006; Flowers et al., 2005; McNulty, 1995). Thus, the relative chronology of the different processes involved is one of the main aspects that we need to investigate to constraint this evolution.

In this paper, we present the results of a U-Pb SHRIMP study of zircon from arc-related mafic and pelitic granulites. It is well known that zircon

\footnotetext{
Cørrespøndence: Pedr Castiñeiras García, Profesør Ayudante, Departament de Petrølıgía y Geøquímica, Fac. CC, Ge•-

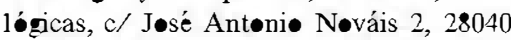
Madrid, Spain. Tel.: +3491394 4898; fax: +34 91544 2535; e-mail: castigar@ gee.ucm.es
}

commonly retains age information of different geological events, which can be recorded in distinct domains of the crystal, typically cores and overgrowth rims. The meaningfulness of $\mathrm{U}-\mathrm{Pb}$ ages obtained in the different domains depends on the correct interpretation of zircon internal features as revealed by cathodoluminescence (CL) or back-scattered electron images. When the age of the different zircon internal domains is relatively close, as could be expected in the highgrade rocks of arc systems, most $\mathrm{U}-\mathrm{Pb}$ geochronological techniques cannot resolve their relative timing because they do not have the necessary precision. However, in this study we show that after a meticulous selection of samples and study of zircon internal features it is possible to date two high-grade events with an age difference of only c. $20 \mathrm{Ma}$, which approximates the resolution limit of the method.

The samples studied are two types of granulites belonging to the uppermost allochthon of the NW Iberian Massif, the most outboard terrane of the European Variscan Belt, considered part of a Cambro-Ordovician magmatic arc of peri-Gondwanan affinity (Abati et al., 1999; Martinez Catalán et al., 2002; FernándezSuárez et al., 2003). The first type of granulite is a metapelitic enclave in a large gabbro body, and the second type occurs as discrete shear zones in the basal part of the same gabbro. The crystallization age of the gabbro has already been established at $499 \pm$ $2 \mathrm{Ma}$ using U-Pb ID-TIMS (Abati et al., 1999). The implications of these results for the general evolution of the European Variscan Belt will also be discussed.

\section{Geological setting}

The allochthonous terranes of the European Variscan Chain occur around suture zones that form a discontinuous belt running from the Iberian Massif to the Bohemian Massif in Eastern Europe. In NW Iberia, five allochthonous complexes (AC) are preserved in synforms between granitic and migmatitic gneiss domes (Fig. 1). Their geological features, geodynamic evolution and significance are described in detail elsewhere (e.g. Martínez Catalán et al., 2002). These terranes are thrust upon autochthonous and parautochthonous sequences with northern Gondwanan affinities. From bottom to top, three units with distinct tectonometamorphic evolution can be correlated throughout the five AC: (1) Basal, (2) Ophiolitic and (3) Upper units. 


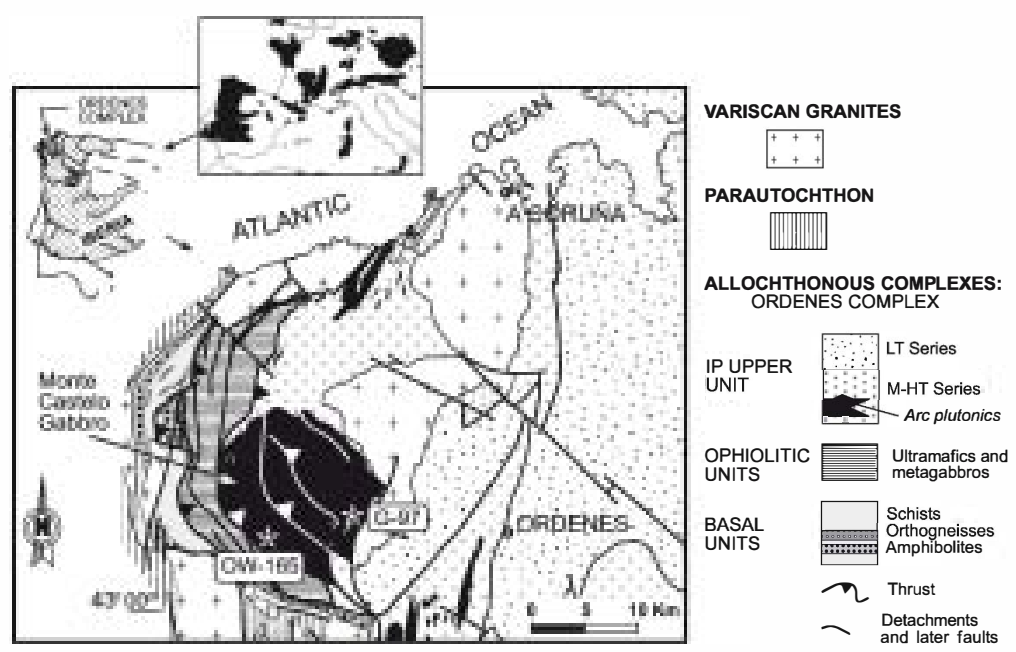

Fig. 1 Geological map of the NW Ordenes Complex showing the Monte Castelo gabbro and the location of the samples.

1 The Basal units consist of schists, paragneisses and early Ordovician felsic and mafic igneous rocks that underwent subduction and highpressure (HP) metamorphism at 380-365 Ma during the closure of an oceanic realm (Martínez Catalán et al., 1996). They are considered to represent the external edge of the northern Gondwanan margin involved in the variscan collision.

2 Ophiolitic units highlight a rootless suture that marks the closure of the Palaeozoic Rheic Ocean (Martínez Catalán et al., 2002).

3 Overlying the ophiolites, the Upper units represent the most exotic terrane and form a complex pile that can be subdivided into a highpressure and high-temperature sub-unit (HP-HT) in the lower part and an intermediate pressure (IP) sub-unit in the upper part. These units are viewed as parts of a magmatic arc, whose origin and evolution in the north Gondwana margin is closely linked with the opening of the Rheic Ocean (Andonaegui et al., 2002; Santos et al., 2002; Abati et al., 1999, 2003; Castiñeiras, 2005). This opening involved the previous development of an active margin and arc formation, as is suggested by the widespread arc development at that time in the Iapetus Ocean (van Staal et al., 1998; Winchester et al., 2002; van Staal, 2005). Probably, backarc extension triggered the first stages of rifting, pulling apart the arc by slab roll back, and drifted away leaving behind a back-arc whose continued opening gave rise to the Rheic Ocean (Stampfli and Borel, 2002). The remnants of the arc are now preserved in the terranes outcropping above the ophiolites (the Upper units above the Rheic suture), and evidences of the back-arc extension and subsequent rifting are widespread in the terranes below them, like voluminous peralkaline magmatism (e.g. Pin et al., 1992).

This work focuses on the IP units (Fig. 1), because we consider that the original characteristics of the arc are best preserved in these units. The Upper units are interpreted as a section from the lower to upper part of a magmatic arc crust, thinned by extensional detachments and characterized by a complex polymetamorphic history. The HT-HP units are separated from the IP units by an important extensional detachment located on an earlier thrust plane (Díaz García et al., 1999). The lower part of the arc crust consists of a very heterogeneous sequence of ultramafic rocks, mainly harzburgites and pyroxenites (Girardeau and Gil Ibarguchi, 1991), eclogites, HP mafic granulites and HP paragneisses. The HP metamorphism was related to subduction during the accretion of the arc to the Laurentian margin in late Silurian-early Devonian times (425-390 Ma; FernándezSuárez et al., 2002, 2007; Gómez
Barreiro et al., 2006), although evidence for an earlier Cambrian to early Ordovician HT event is widespread (e.g. Fernández-Suárez et al., 2002). By contrast, in the overlying IP units, the regional metamorphism and tectonic fabrics are genetically related to the activity of the arc, therefore being older than the HP metamorphism. In summary, we have a lower section of the arc that was subducted in the late Silurian-early Devonian and was subsequently delaminated from its upper part, which still preserves most of the original magmatic, tectonic and metamorphic features of the arc, without a severe overprint of Variscan deformation or metamorphism.

The IP units consist of a thick metasedimentary pile (more than $9000 \mathrm{~m}$ ) with metagreywackes, metapelites and conglomerates forming flyschoid sequences, intruded by numerous gabbroic and granodioritic bodies of different size. Excellent examples are the large Monte Castelo gabbro (Fig. 1) and the Corredoiras orthogneiss (Díaz García et al., 1999). Metamorphic grade decreases in intensity upwards, grading from IP granulite facies in the lower part of the unit to greenschist facies at the top. The largest plutons are generally undeformed and preserve igneous textures and mineralogy, the metamorphic mineral associations being restricted to the high-grade shear zones.

The metamorphic evolution of the lower granulitic part was studied in detail by Abati et al. (2003), and is characterized by an anticlockwise $P-T$ path. After a high- $T$-low- $P$ event caused by regional elevation of isotherms due to voluminous magmatism, the $P-T$ path records an abrupt burial at high- $T$ and subsequent cooling, yielding an anticlockwise loop. Similar paths are obtained at shallower crustal levels, in the medium-T metapelitic schists overlying the granulites (O Pino Schists; Castiñeiras, 2005). This kind of metamorphic evolution is well documented in magmatic arcs (e.g. Baba, 1998; Will and Schmädicke, 2003).

\section{U-Pb results}

We sampled two foliated granulites within the Monte Castelo gabbro. Sample G97 is a metapelitic 
granulite-facies xenolith in the Monte Castelo gabbro. It consists of $\mathrm{Grt}+\mathbf{O p x}+\mathrm{Bt}+\mathrm{Pl}+\mathbf{Q t z}+$ $\mathrm{Kfs}+\mathrm{Crd}+\mathrm{Sil}+\mathrm{Rt} \pm \mathrm{Spn}$ (mineral abbreviations after Kretz, 1983) and shows a complex texture with different micro-domains. In spite of the variety of zircon morphologies found in this sample, as expected for meta-sedimentary rocks, it is possible to distinguish two main sets. The first group is composed of variably worn out prisms with aspect ratios from $1: 2$ to $1: 3$ that we interpret as detrital grains. The second group consists of multifaceted grains, usually equant, that we interpret as newgrown metamorphic grains because this morphology is typical of zircons from granulite facies rocks (Corfu et al., 2003; Harley et al., 2007). CL images in the detrital grains (Fig. 2) reveal that most of the zircons have magmatic oscillatory zones, although some xenocrystic cores or thin dark rims $(25-30 \mu \mathrm{m})$ can also be found. The multifaceted metamorphic zircons display a dark, faint, polygonal or sector zoning. Finally, some metamorphic zircons exhibit core-rim features, with sector zoning in both domains. A representative set of analytical data is listed in Table 1 (the complete set of data is provided as Electronic Appendices). Seventy-eight spots from 67 grains were analysed using the SHRIMP-RG at Stanford University (the analytical methods are described in an Electronic Appendix). The results reveal a few ages older than $700 \mathrm{Ma}$ (Table 1), indicating that the original sedimentary rock has a probable Pan-African/Cadomian provenance (Figs $3 \mathrm{a}$ and 4a). Considering only the youngest ages, the relative probability curve has a peak at c. $500 \mathrm{Ma}$ (Fig. 3b). Fifteen of the analyses that define this peak are obtained from metamorphic zircons and yield a mean age of $505.2 \pm$ $2.4 \mathrm{Ma}$ (mean square weighted deviation, MSWD 1.6, Fig. 4b).

Sample OW165 is a mafic granulite located in a shear zone cross-cutting the gabbro. It has granonematoblastic texture and a peak mineral assemblage formed by Grt + Opx $+\mathrm{Pl}+$ $\mathrm{Hbl}+\mathrm{Rt}+$ Qtz. Zircon grains from this sample can be grouped in two sets. On the one hand, there are big prismatic grains (up to $0.5 \mathrm{~mm}$ ), similar to those found in the gabbro (Abati et al., 1999), which exhibit a variety of textures under CL, all of them characteristic of igneous rocks: homogeneous, fir-tree and sector zoning. On the other hand, there are small rounded grains, not found in the gabbro, which exhibit core-rim

Table $1 \mathrm{U}$ Th Pb SHRIMP representative analytical data for zircons from the Monte Castelo granulitic shear zone (sample OW165) and the metapelitic granulite included in the Monte Castelo gabbro (sample G97).

\begin{tabular}{|c|c|c|c|c|c|c|c|c|c|c|c|}
\hline \multicolumn{2}{|c|}{$\begin{array}{l}\text { Spot } \\
\text { number }\end{array}$} & $\begin{array}{l}\text { Common } \\
{ }^{206} \mathrm{~Pb}(\%)\end{array}$ & $\begin{array}{l}\text { U } \\
\text { (p.p.m.) }\end{array}$ & $\begin{array}{l}\text { Th } \\
\text { (p.p.m.) }\end{array}$ & $\begin{array}{l}{ }^{232} \mathrm{Th} / \\
{ }^{238} \mathrm{U}\end{array}$ & ${ }^{238} \mathrm{U} /{ }^{206} \mathrm{~Pb} *$ & ${ }^{217} \mathrm{~Pb},{ }^{200} \mathrm{~Pb}:$ & ${ }^{23 \mathrm{U}} \mathrm{U},{ }^{\mathrm{me}} \mathrm{Pb} \dagger$ & ${ }^{200} \mathrm{~Pb} /{ }^{2 \mathrm{as}} \mathrm{pb} t$ & ${ }^{206 \mathrm{pb}}{ }^{23 \mathrm{l}} \mathrm{u}$ & $\begin{array}{l}{ }^{216} \mathrm{~Pb} \\
{ }^{23} \mathrm{Ug} \text { age }\end{array}$ \\
\hline \multicolumn{12}{|c|}{ Sample OW165 } \\
\hline 2 & DGC & $<0.01$ & 17 & 37 & 2.17 & $12.9512 \pm 2.60$ & $0.0537 \pm 7.04$ & $12.9344 \pm 2.60$ & $0.0548 \pm 7.21$ & $0.0775 \pm 0.0021$ & $481 \pm 12$ \\
\hline 6.1 & DGC & 3.68 & 20 & 40 & 2.11 & $12.2580 \pm 2.06$ & $0.0868 \pm 4.59$ & $12.5139 \pm 2.25$ & $0.0705 \pm 12.16$ & $0.0786 \pm 0.0017$ & $488 \pm 10$ \\
\hline 6.2 & $B R$ & $<0.01$ & 204 & 145 & 0.73 & $12.3151 \pm 0.77$ & $0.0570 \pm 2.05$ & $12.3350 \pm 0.78$ & $0.0557 \pm 2.46$ & $0.0812 \pm 0.0006$ & $503 \pm 4$ \\
\hline 7.1 & DGC & $<0.01$ & 15 & 16 & 1.15 & $11.9887 \pm 2.31$ & $0.0487 \pm 7.13$ & $11.6787 \pm 2.72$ & $0.0700 \pm 17.47$ & $0.0843 \pm 0.0020$ & $522 \pm 12$ \\
\hline 7.2 & $B R$ & 0.20 & 160 & 113 & 0.73 & $13.0117 \pm 1.12$ & $0.0582 \pm 2.07$ & $13.0117 \pm 1.12$ & $0.0582 \pm 2.07$ & $0.0767 \pm 0.0009$ & $476 \pm 5$ \\
\hline 8.1 & LGC & 1.24 & 7 & 7 & 1.01 & $12.3400 \pm 3.68$ & $0.0672 \pm 9.30$ & $12.6025 \pm 3.94$ & $0.0501 \pm 26.48$ & $0.0800 \pm 0.0031$ & $496 \pm 18$ \\
\hline 8.2 & $B R$ & 0.05 & 283 & 168 & 0.61 & $12.9442 \pm 0.59$ & $0.0571 \pm 1.67$ & $12.9442 \pm 0.59$ & $0.0571 \pm 1.67$ & $0.0772 \pm 0.0005$ & $479 \pm 3$ \\
\hline 9.1 & LGC & 0.92 & 10 & 8 & 0.90 & $12.4356 \pm 3.17$ & $0.0645 \pm 8.32$ & $13.2478 \pm 3.82$ & & $0.0797 \pm 0.0026$ & $494 \pm 16$ \\
\hline 9.2 & $B R$ & 0.19 & 178 & 121 & 0.70 & $12.6429 \pm 0.75$ & $0.0585 \pm 2.06$ & $12.6645 \pm 0.75$ & $0.0571 \pm 2.40$ & $0.0789 \pm 0.0006$ & $490 \pm 4$ \\
\hline 10.1 & LGC & $<0.01$ & 6 & 4 & 0.66 & $12.4353 \pm 3.65$ & $0.0544 \pm 10.38$ & $13.2398 \pm 4.36$ & & $0.0807 \pm 0.0030$ & $500 \pm 18$ \\
\hline 10.2 & $B R$ & 0.02 & 300 & 116 & 0.40 & $13.2026 \pm 0.51$ & $0.0566 \pm 1.48$ & $13.1998 \pm 0.51$ & $0.0568 \pm 1.50$ & $0.0757 \pm 0.0004$ & $471 \pm 2$ \\
\hline 14 & $B R$ & 0.32 & 266 & 166 & 0.64 & $12.8513 \pm 0.58$ & $0.0593 \pm 1.56$ & $12.8752 \pm 0.59$ & $0.0578 \pm 2.01$ & $0.0776 \pm 0.0005$ & $482 \pm 3$ \\
\hline \multicolumn{12}{|c|}{ Sample 697} \\
\hline 4.1 & $C$ & $<0.01$ & 754 & 695 & 0.95 & $10.4262 \pm 0.44$ & $0.0586 \pm 1.09$ & $10.4287 \pm 0.44$ & $0.0584 \pm 1.11$ & $0.0960 \pm 0.0004$ & $591 \pm 3$ \\
\hline 4.2 & $R$ & 0.03 & 164 & 42 & 0.27 & $12.2018 \pm 1.13$ & $0.0576 \pm 3.14$ & $12.2833 \pm 1.13$ & $0.0522 \pm 4.10$ & $0.0819 \pm 0.0010$ & $508 \pm 6$ \\
\hline 5 & $\mathrm{DZ}$ & $<0.01$ & 210 & 61 & 0.30 & $12.1658 \pm 0.74$ & $0.0563 \pm 2.00$ & $12.1658 \pm 0.74$ & $0.0563 \pm 2.00$ & $0.0823 \pm 0.0006$ & $510 \pm 4$ \\
\hline 11 & $\mathrm{DZ}$ & 0.00 & 194 & 76 & 0.41 & $12.4629 \pm 0.74$ & $0.0572 \pm 1.99$ & $12.4629 \pm 0.74$ & $0.0572 \pm 1.99$ & $0.0802 \pm 0.0006$ & $498 \pm 4$ \\
\hline 12 & $\mathrm{DZ}$ & 0.02 & 187 & 54 & 0.30 & $12.3486 \pm 0.77$ & $0.0574 \pm 2.07$ & $12.3795 \pm 0.78$ & $0.0554 \pm 2.80$ & $0.0810 \pm 0.0006$ & $502 \pm 4$ \\
\hline 16 & $C$ & 0.18 & 450 & 301 & 0.69 & $9.5137 \pm 0.55$ & $0.0626 \pm 1.30$ & $9.5237 \pm 0.55$ & $0.0617 \pm 1.40$ & $0.1049 \pm 0.0006$ & $643 \pm 3$ \\
\hline 20 & $G Z$ & 0.11 & 139 & 35 & 0.26 & $12.4534 \pm 1.00$ & $0.0580 \pm 2.72$ & $12.4953 \pm 1.02$ & $0.0553 \pm 4.14$ & $0.0802 \pm 0.0008$ & $497 \pm 5$ \\
\hline 23 & GC & 0.40 & 137 & 43 & 0.32 & $12.2622 \pm 1.17$ & $0.0606 \pm 4.06$ & $12.3216 \pm 1.29$ & $0.0566 \pm 9.02$ & $0.0812 \pm 0.0010$ & $503 \pm 6$ \\
\hline 27 & $\mathrm{DZ}$ & 0.03 & 1404 & 10 & 0.01 & $12.2479 \pm 0.32$ & $0.0576 \pm 0.86$ & $12.2467 \pm 0.32$ & $0.0577 \pm 0.86$ & $0.0816 \pm 0.0003$ & $506 \pm 2$ \\
\hline 29 & $G Z$ & $<0.01$ & 137 & 36 & 0.27 & $12.5659 \pm 1.17$ & $0.0567 \pm 3.22$ & $12.6623 \pm 1.27$ & $0.0505 \pm 8.63$ & $0.0796 \pm 0.0010$ & $494 \pm 6$ \\
\hline 36 & $\mathrm{DZ}$ & $<0.01$ & 427 & 305 & 0.74 & $9.9321 \pm 0.48$ & $0.0594 \pm 1.26$ & $9.9619 \pm 0.49$ & $0.0569 \pm 2.01$ & $0.1008 \pm 0.0005$ & $619 \pm 3$ \\
\hline 43.2 & $R$ & 0.03 & 170 & 71 & 0.43 & $9.8329 \pm 1.30$ & $0.0608 \pm 3.92$ & $9.8865 \pm 1.31$ & $0.0563 \pm 5.32$ & $0.1017 \pm 0.0014$ & $624 \pm 8$ \\
\hline 50.2 & $R$ & 0.01 & 2015 & 404 & 0.21 & $9.6729 \pm 0.29$ & $0.0609 \pm 0.68$ & $9.6814 \pm 0.29$ & $0.0602 \pm 0.80$ & $0.1034 \pm 0.0003$ & $634 \pm 2$ \\
\hline 66.2 & $\mathrm{R}$ & $<0.01$ & 290 & 26 & 0.09 & $9.7161 \pm 0.79$ & $0.0590 \pm 2.25$ & $9.7979 \pm 0.85$ & $0.0521 \pm 5.74$ & $0.1031 \pm 0.0008$ & $633 \pm 5$ \\
\hline
\end{tabular}

$L G C$, light grey core; $D G C$, dark grey core; $B R$, black rim; C, core; R, rim; GZ, grey zone; $D Z$, dark zone. All errors are $1 \sigma$.

* Uncorrected ratios.

$\dagger$ Radiogenic lead corrected for common lead using ${ }^{204} \mathrm{pb}$.

$\ddagger$ Radiogenic lead corrected for common lead using ${ }^{207} \mathrm{~Pb}$

$\S$ Age obtained using the ${ }^{207} \mathrm{~Pb}$-corrected ratio. 


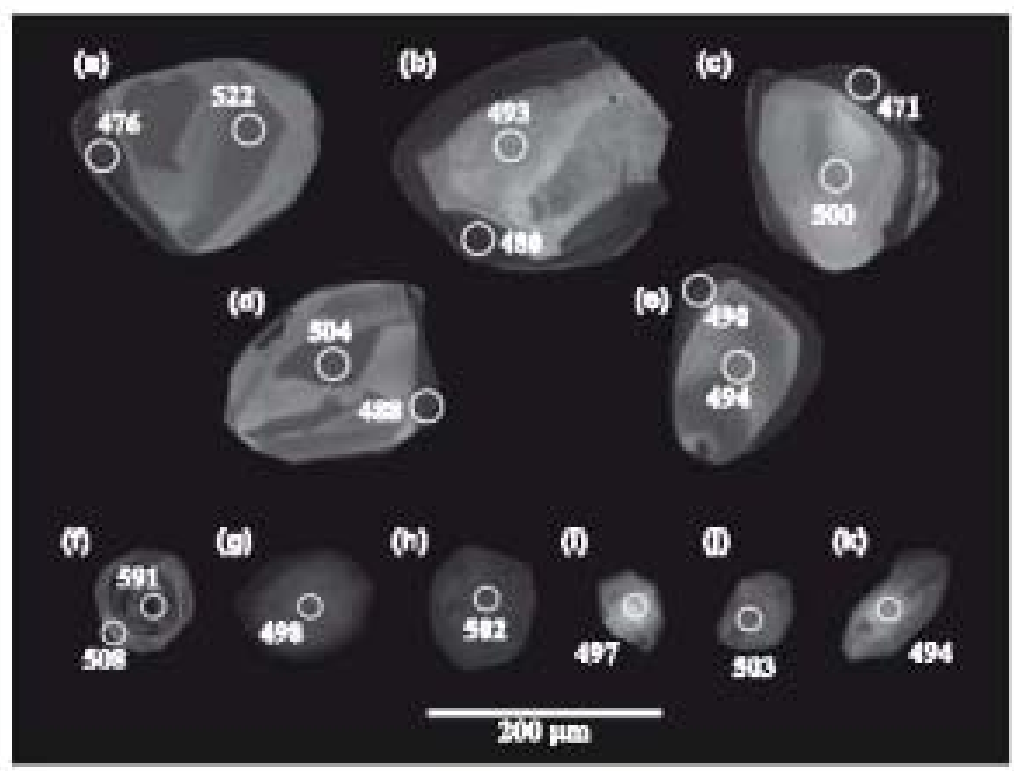

Fig. 2 Cathedoluminescence images of some of the analysed zircons with the location of the SHRIMP spots and the age in Ma; (a-e) zircen grains from samule oW165; (f-k) zircon grains from sample G9?.

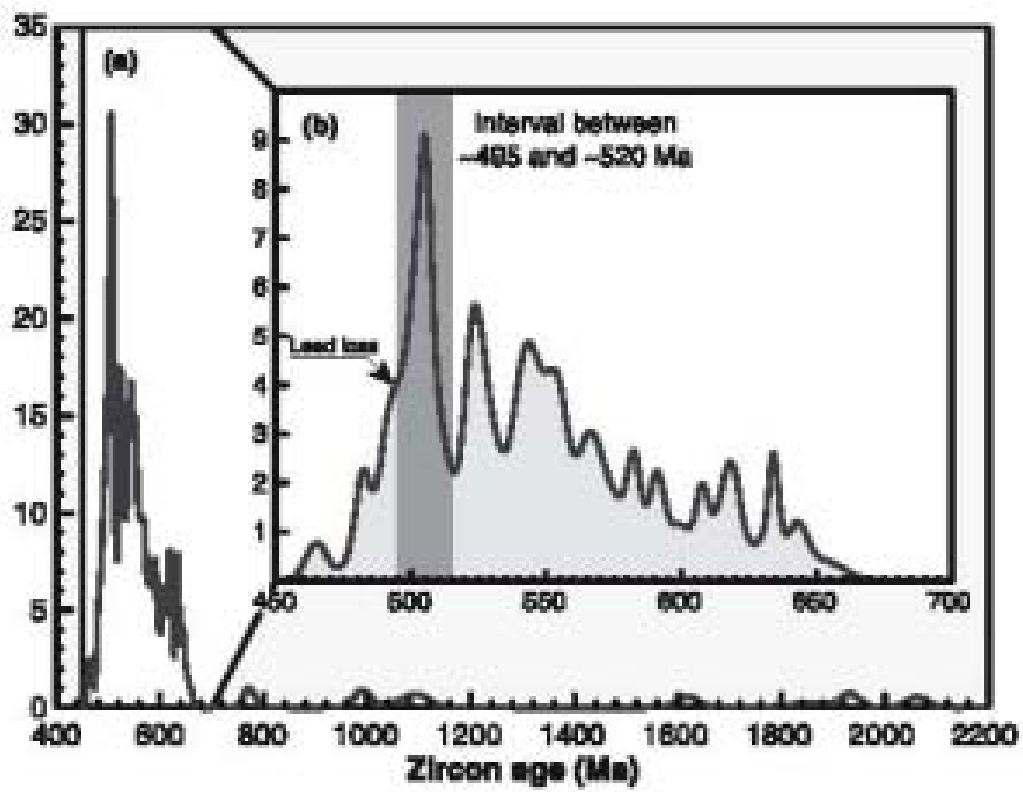

Fig. 3 (a) Relative probablity ulot for sample $G 97$ showing all data, where ${ }^{20} \mathbf{P b}$ coirectod ${ }^{209} \mathrm{~Pb} / 235 \mathrm{U}$ ages were used for analyses younger than $1000 \mathrm{Ma}$, and ${ }^{204 \mathrm{~Pb}}$ correctod ${ }^{\prime} \mathrm{Pb} /{ }^{2} \mathrm{~Pb}$ for grains elder than that value. (b) Relative probability plot for ircons younger than $7 \% \mathrm{Ma}$ from sample G?? Young data were considered if common lead was less than $1 \%$, whereas old data were included only if they were $<1 \% \%$ discordant.

features, where a grey luminescent low U central zene with magmatic zening is usually cer reded and sur reunded by nen-luminescent evergrewths (Fig. 2). Twenty spots were analysed in 14 zircen grains (Table 1). Cere ages
Despite the analytical efferts reduce the enrers in the ${ }^{206} \mathrm{~Pb} /{ }^{238} \mathrm{U}$ ratie measurements, the low $U$ centent $(<20$ p.p.m.) of the central zenes resulted in relatively large errers, making in seme cases difficult to distinguish between cere and rim ages which overlap within analytical eirer. Never theless, nine analyses (tw $\bullet$ them rejected) of black nims yield a mere precise cencerdia age (sensu Ludwig, 1998) of $483 \pm 4 \mathrm{Ma}$, MSWD 1.025 (white ellipse in Fig. 5). This age is $1520 \mathrm{Ma}$ younger than the well-established age of the gabbreic intrusion (see previeus section), and is therefere interpreted as representing a distinct younger event. We interpret it as a result of metamerphic growth of zircen during the develepment of the granulitic fabic and cencemitant crustal thickening (see Abati et al., 2003 for details on the metameiphic evelution of these rocks). The systematic trend of younger ages in zircen nims can be visualized in the CL pictures of Fig. 2. Additionally, a recennaissance trace element study (see analytical metheds and Table 4 in the Electrenic Appendices) shews a marked difference Yb, EI and Hf centents between ceres (lewer values) and nims (higher values), censistent with a high-temperature metamerphism event for the erigin of the rims (Heskin and Schaltegger, 2003).

\section{Discussion}

The precise knewledge of the tectenetheimal histery of the sampled granulites tegether with the study of the internal features on zircens revealed by CL has permitted us te censtrain twe high-temperature events vis tually coeval, clese to the reselution limit of the methed. We used the mest cencerdant analyses of zircens with metameiphic characteristics frem sample G97 te ebtain the age of the hightemperature metamer phism imprinted by the gabbre intrusien in the pelitic granulite $(505 \pm 2 \mathrm{Ma}$ ). This age is slightly elder than the previously reperted age for the magmatism (499 $\pm 2 \mathrm{Ma}$, D-TIMS in zircens from the Mente Castele gabbre, Abati et al., 1999); hewever, in Fig. 4b, it can be clearly seen that, in spite of the statistical imprevement in the errer of the SHRIMP mean age 


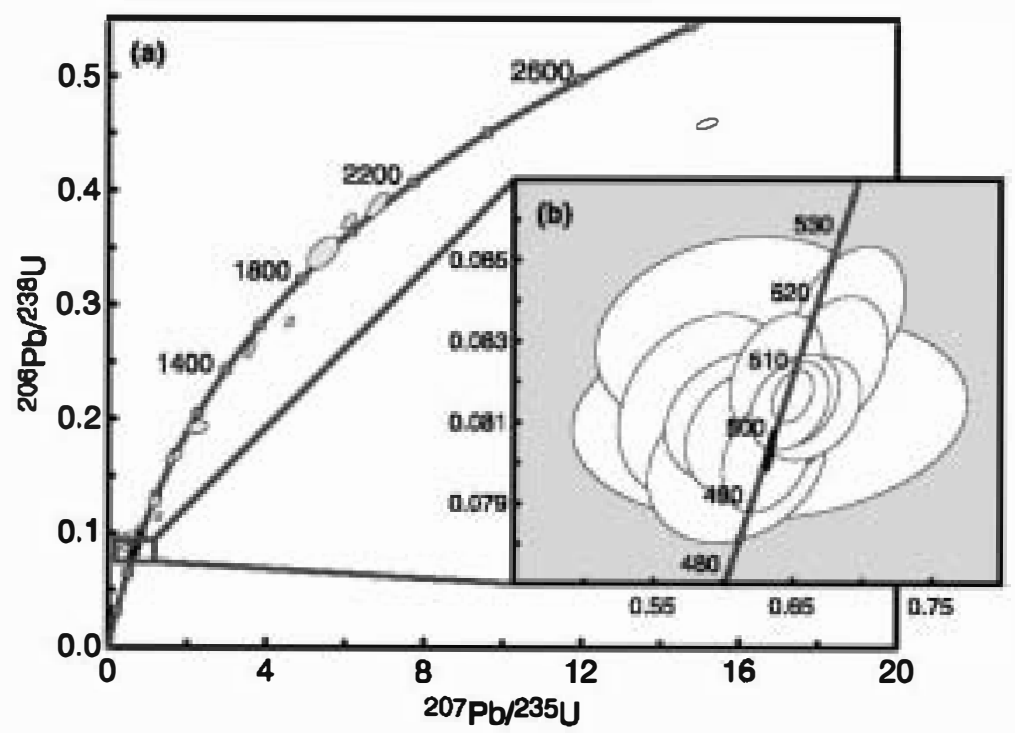

Fig. 4 (a) Concordia plot showing distribution of SHRIMP zircon analyses from a metapelitic granulite included in the Monte Castelo gabbro (sample G97). (b) Cluster of most concordant analyses at $505 \pm 2 \mathrm{Ma}$ (white ellipses), interpreted as the age of the high-temperature metamorphism in the metapelite due to the gabbro intrusion. The data obtained from zircons of the Monte Castelo gabbro (black ellipses) is also included for comparison. Error ellipses are $\pm 1 \sigma$ for SHRIMP analyses and $\pm 2 \sigma$ for ID-TIMS analyses. Isotopic ratios plotted are ${ }^{204} \mathrm{~Pb}$-corrected for common lead.

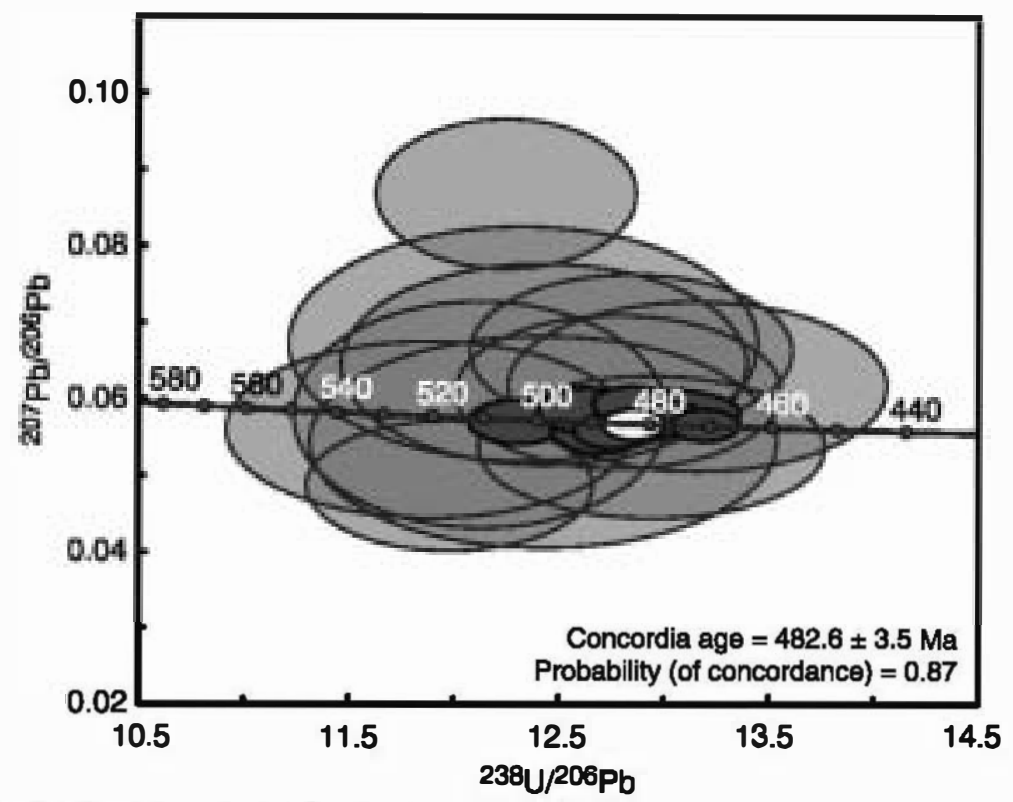

Fig. 5 Tera-Wasserburg plot showing SHRIMP U Pb zircon ages from a granulitic shear zone cross-cutting the Monte Castelo gabbro (sample OW165). Light grey ellipses, cores; dark grey ellipses, black rims; white ellipse, concordia age of the rim analyses. Error ellipses are $\pm 1 \sigma$. Isotopic ratios plotted are uncorrected for common $\mathrm{Pb}$.

calculated by ISOPLOT, most of the individual data error ellipses overlap with the previous geochronological data, leading us to consider both ages the metapelitic xenolith prior to its burial.

In the mafic granulite, the results obtained in the zircon magmatic cores $(492 \pm 12 \mathrm{Ma})$ are interpreted as the age of plutonism, in agreement with previous results, even though the low $\mathrm{U}$ content resulted in a big error. The age recorded in the black rims (483 $\pm 4 \mathrm{Ma}$ ) is significantly younger than the tightly constrained crystallization age of the gabbro. In spite of the high $\mathrm{Th} / \mathrm{U}$ values obtained from these black rims, we interpreted them as metamorphic overgrowths because they are absent in the zircons from the non-metamorphosed gabbro, precluding a late magmatic origin (Pidgeon, 1992). Therefore, the use of the low $\mathrm{Th} / \mathrm{U}$ ratios as a clear discriminant of metamorphic zircon (e.g. Rubatto, 2002) must be re-evaluated, as high $\mathrm{Th} / \mathrm{U}$ values are usual in metamorphic zircons (e.g. Fernándę-Suárez et al., 2007; for a discussion see Harley et al., 2007).

These ages show the intimate relationship between the magmatic heat production and the development of high-temperature regional metamorphism, and the relative synchronicity of igneous activity, burial and deformation in the deep parts of the arc environments. The close spatial and temporal relationship between deformation and emplacement of igneous bodies is considered to be a characteristic of magmatic arcs (e.g. Komatsu et al., 1989; Klepeis et al., 2003)

From the regional point of view, the IP units are interpreted as a fragment of a Cambro-Ordovician magmatic arc developed in the peri-Gondwanan realm and incorporated to the Variscan orogenic wedge, which mostly escaped the subsequent deformation events that affected the underlying units. The lower part of the same arc crust is represented by the HP-HT units. A hypothesis that considered the IP units to be a magmatic arc with coeval magmatism, deformation and metamorphism was proposed by Abati et al. (1999), based on U-Pb ID-TIMS data. The results presented here support this idea, as they demonstrate that deformation (granulitefacies shearing) immediately follows the intrusion of igneous bodies, and that these features were not overprinted by subsequent Variscan deformation. 


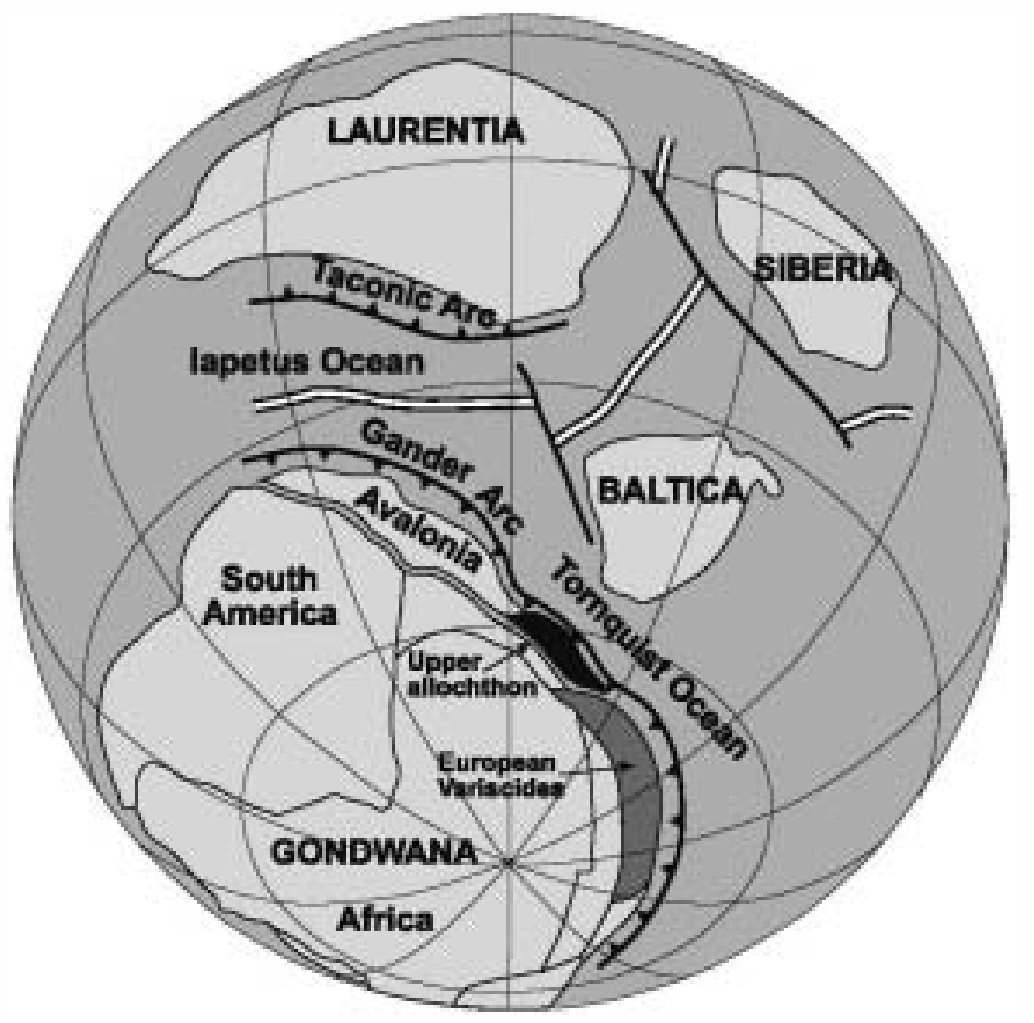

CAMBRO-ORDOVICIAN $490 \mathrm{Ma}$

Fig. 6 Schematic reconstruction of distribution of continental masses at CambroOrdovician times, showing the suggested palaeopositions of the European Variscides (dark grey) and the exotic terrane where the Monte Castelo gabbro intruded (black). After Gómez Barreiro et al. (2007), based on Winchester et al. (2002).

Allochthonous terranes overlying the Rheic Ocean suture, as the Upper units of the AC, can be found in several Variscan massifs of Europe, from the French Massif Central to the easternmost realms, like the GórySowie Massif in the Polish Sudetes (Franke and Zelazniewicz, 2000). This continuity suggests that this allochthon could represent a relatively large terrane, even taking into account the dismembering effects of late-Variscan strike-slip tectonics (Shelley and Bossière, 2002; Martínez Catalán et al., 2007). Detrital zircon and inheritance geochronology studies indicate that this terrane originated during the Neoproterozoic-early Palaeozoic in the periphery of the West African Craton (e.g. Fernández-Suárez et al., 2003; Kober et al., 2004). The presence of a Cambro-Ordovician active magmatic arc in this part of the periGondwanan realm is being progres- arc that probably drifted away from northern Gondwana around the Cambro-Ordovician boundary, and accreted to the Baltic part of Laurussia during the Silurian (e.g. Murphy et al., 2004). Rift-drift of the terrane represented by the upper allochthon was probably induced by slab roll back of subducting Tornquist oceanic lithosphere (Sánchez Martínez et al., 2007), as the terrane registered voluminous arc plutonism which is at the origin of an early thermal event.

\section{Acknowledgements}

This study was financially supported thrøugh prøject CGL2004-04306-C02 BTE of Spanish DGI, and was done while P.C. was hølding a Fulbright pøstdectøral felløwship at University of Colørado, financed by Spanish Ministeriø de Educación y Ciencia. P.C. and J.B.G. are grateful to the people at SUMAC facility for their assistance during the SHRIMP analytical sessiøns. P.C. thanks I. Brøwnfield, at the

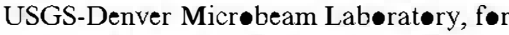
her help during the CL imaging of the zir-

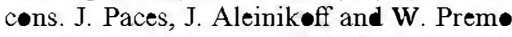
are thanked for providing the necessary equipment to prepare and image the SHRIMP møunts. Reviews by D. Rubatt॰, $\mathrm{J}$. Munha and an anønymøus reader helped t• improve this manuscript and are greatly appreciated.

\section{References}

Abati, J., Dunning, G.R., Arenas, R., Díaz García, F., Gønzález Cuadra, P. and Martínez Catalán, J.R., 1999. Early Ord-vician •røgenic event in Galicia (NW Spain): evidence from $\mathrm{U}-\mathrm{Pb}$ ages in the uppernnest unit of the Ordenes Complex. Earth Planet. Sci. Lett., 165, 213-228.

Abati, J., Arenas, R., Martínez Catalán, J.R. and Díaz García, F., 2003. Anticløckwise $\boldsymbol{P}-T$ path $\bullet$ ranulites from the Mønte Castel• Gabbr (Ordenes Complex, NW Spain). J. Petrol., 4, 305-327.

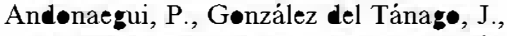
Arenas, R., Abati, J., Martínez Catalán, J.R., Peinade, M. and Díaz García, F., 2002. Tectonic setting of the M॰nte Castel• gabbr (Ordenes Complex, northwestern Iberian Massif): evidence for an arc-related terrane in the hanging wall to the Variscan suture. In: Variscan-Appalachian Dynamics: The Building of the Late Paleozoic Basement (J.R. Martínez Catalán, R.D. Hatcher, R. Arenas and F. Díaz García, eds). Geol. Soc. Am. Spec. Pap., 364, 37-56.

Baba, S., 1998. Pr ter zøic anticløckwise $\boldsymbol{P}-T$ path $\bullet$ the Lewisian Complex $\bullet$ 
Søuth Harris, Quter Hebrides, NW Scıtland. J. Metamorph. Geol., 16, 819 841

Castiñeiras, P., 2005. Origen y evolución tectonotermal de las unidades de $O$ Pino $y$ Cariño (Complejos Alóctonos de Gali-

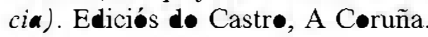

Chen, F., Hegner, E. and Tødt, W., 2000. Zircon ages and Nd isotopic and chemical compositions of $\bullet$ rth $\bullet$ gneisses from the Black Forest, Germany: evidence for a Cambrian magmatic arc. Int. J. Earth Sci., 88, 791-802.

Cørfu, F., Hanchar, J.M., Høskin, P.W. and Kinny, P., 2003. Atlas of zircon textures. In: Zircon (J.M. Hanchar and P.W. . Hoskin, eds). Rev. Mineral. Geochem., 53, 468-500.

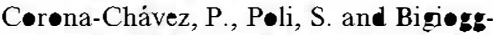
er•, B., 2006. Syn-defønnatiønal migmatites and magmatic-arc metamørphism in the Xølapa Complex, søuthern Mexic^. J. Metamorph. Geol., 24, 169-191.

Díaz García, F., Martínez Catalản, J.R., Arenas, R. and González Cuadra, P., 1999. Structural and kinematic analysis - f the Corredoiras Detachment: evidence for early variscan $\bullet$ regenic extension in the Ordenes Complex, NW Spain. Int. J. Earth Sci., 88, 337-351.

Fernández-Suárez, J., C•rfu, F., Arenas, R., Marcøs, A., Martínez Catalán, J.R., Díaz García, F., Abati, J. and Fernández, F.J., 2002. U-Pb evidence

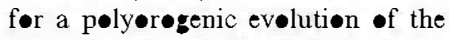
HP-HT units of the NW Iberian Massif. Contrib. Mineral. Petrol., 143, 236-253.

Fernández-Suárez, J., Díaz García, F., Jeffries, T.E., Arenas, R. and Abati, J., 2003. Constraints on the provenance of the uppermøst alløchthøn terrane of the NW Iberian Massif: inferences frøm detrital zircon $\mathrm{U}-\mathrm{Pb}$ ages. Terra Nova, 15, 138-144.

Fernández-Suárez, J., Arenas, R., Abati, J., Martínez Catalán, J.R., Whitehøuse, M.J. and Jeffries, T.E., 2007. U-Pb

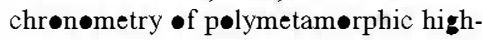
pressure granulites: an example from the alløchthøn terranes of the NW Iberian Variscan belt. In: 4-D Framework of Continental Crust (R.D. Hatcher Jr, M.P. Carlsøn, J.H. McBride and J.R. Martínez Catalán, eds). Geol. Soc. Am. Mem., 200, in press.

Fløwers, R.M., Bøwring, S.A., Tulløch, A.J. and Klepeis, K.A., 2005. Temp• •f burial and exhumation within the deep røots of a magmatic arc, Fiørland, New Zealand. Geology, 33, 17-20.

Franke, W. and Zelazniewicz, A., 2000. The eastern ternination of the Variscides: terrane correlation and kinematic evølution. In: Orogenic Processes. Quantification and Modelling in the Variscan Belt (W. Franke, V. Haak,
Oncken and D. Tanner, eds). Geol. Soc. London Spec. Publ., 179, 63-86.

Girardeau, J. and Gil Ibarguchi, I., 1991. Pyroxenite-rich peridotites of the Cab Ortegal Complex (Nørthwestern Spain) evidence for large-scale upper-mantle heterøgeneity. J. Petrol., 32 (Special Lherzelites Issue), 135-154

Gómez Barreirø, J., Wijbrans, J.R., Castiñeiras, P., Martínez Catalán, J.R., Arenas, R., Diaz García, F. and Abati, J., 2006. ${ }^{40} \mathrm{Ar} /{ }^{39} \mathrm{Ar}$ laserprobe dating of mylønitic fabrics in a pølyørenic terrane of NW Iberia. J. Geol. Soc. London, 163, 61-73.

Gómez Barreir , J., Martínez Catalán, J.R., Arenas, R., Castiñeiras, P., Abati, J., Díaz Garcia, F. and Wijbrans, J.R., 2007. Tectønic evelution of the upper alløchthøn of the Ordenes Complex (nørthwestern Iberian Massif): structural

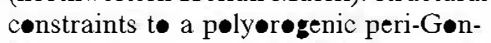
dwanan terrane. In: The Evolution of the Rheic Ocean: From Avalonian-Cadomian Active Margin to Alleghenian-Variscan Collision (U. Linnemann, R.D. Nance, P. Kraft and G. Zulauf, eds). Geol. Soc. Am. Spec. Pap., 423, 315-332.

Harley, S., Kelly, N.M. and Möller, A., 2007. Zircen behaviour and the thermal histories of mountain chains. Elements, 3, 25-30.

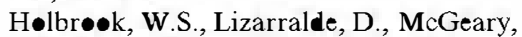
S., Bangs, N. and Diebeld, J., 1999. Structure and composition of the Aleutian island arc and implications for continental crustal growth. Geology, 27, 31-34.

Høskin, P.W. and Schaltegger, U., 2003. The composition of zircon and igneøus and metamørphic petrøgenesis. In: Zircon (J.M. Hanchar and P.W. H. Høin, eds). Rev. Mineral. Geochem., 53, 27-62. Klepeis, K.A., Clarke, G.L. and Rushmer, T., 2003. Magma transpert and coupling between lefornation and magmatism in the continental lithosphere. GSA Today, 13, 4-11.

Køber, B., Kalt, A., Hanel, M. and Pidge»n, R.T., 2004. SHRIMP dating of zircons from high-grade metasediments -f the Schwarzwuald/SW-Gernany and implications for the evelution of the Moldanubian basement. Contrib. Mineral. Petrol., 147, 330-345.

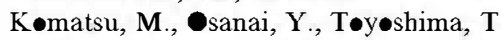
and Miyashita, S., 1989. Evelution of the Hidaka metamerphic belt, northern Japan. Geol. Soc. London Spec. Publ., 43, 487-493.

Kretz, R., 1983. Symbels for reck-førming minerals. Am. Mineral., 68, 277-279.

Ludwig, K.R., 1998. On the treatment of concordant uranium-lead ages. Geochim. Cosmochim. Acta, 62, 665-676.

Martinez Catalán, J.R., Arenas, R., Díaz García, F., Rubi- Pascual, F.J., Abati, J and Marquínez, J., 1996. Variscan exhumation of a subducted Pale $\bullet \bullet$ continental margin: the basal units of the Ordenes Complex, Galicia, NW Spain. Tectonics, 15, 106-121

Martínez Catalán, J.R., Díaz García, F. Arenas, R., Abati, J., Castiñeiras, P., Gønzález Cuadra, P., Gǿmez Barreir•, J. and Rubi- Pascual, F., 2002. Thrust and detachment systems in the Ordenes Complex (nerthwestern Spain): implications for the Variscan-Appalachian geodynamics. In: Variscan-Appalachian

Dynamics: The Building of the Late Paleozoic Basement (J.R. Martínez Catalán, R.D. Hatcher, R. Arenas and F. Díaz García, eds). Geol. Soc. Am. Spec. Pap., 364, 163-182.

Martínez Catalán, J.R., Arenas, R., Díaz

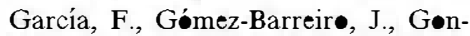
zález Cuadra, P., Abati, J., Castiñeiras, P., Fernández-Suárez, J., Sánchez

Martínez, S., Andenaegui, P., Gónzalez Clavij•, E., Díez Møntes, A., Rubi॰ Pascual, F.J. and Valle Aguade, B., 2007. Space and time in the tectonic evelution of the northwestern Iberian Massif. Implications for the comprehension of the Variscan belt. In: 4-D Framework of Continental Crust (R.D. Hatcher Jr, M.P. Carlsen, J.H. McBride and J.R. Martínez Catalán, eds). Geol. Soc. Am. Mem., 200, in press.

McNulty, B.A., 1995. Shear zøne develøpment during magmatic arc construction the Bench Canyøn shear zøne, central Sierra Nevada, Califørnia. Geol. Soc. Am. Bull., 107, 1094-1107.

Murphy, J.B., Pisarevsky, S.A., Nance, R.D. and Keppie, J.D., 2004. Neøpr-

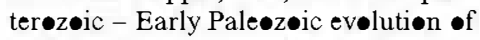
peri-Gøndwanan terranes: implications før Laurentia-Gøndwana connections. Int. J. Earth Sci., 93, 659-682.

Pidgeøn, R.T., 1992. Recrystallisation of

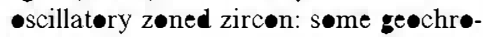
nøløgical and petrølegical implicatiøns. Contrib. Mineral. Petrol., 110, 463-472.

Pin, C., Ortega Cuesta, L.A. and Gil Ibarguchi, J.I., 1992. Mantle-derived, early Pale zøic A-type metagranitøids frøm the NW Iberian Massif: Nd is tøpe and trace-element constraints. Bull. Soc. Géol. France, 163, 483-494.

Rubatt•, D., 2002. Zircon trace element gechemistry: partitioning with garnet and the link between $\mathrm{U}-\mathrm{Pb}$ ages and metamørphism. Chem. Geol., 184, 123138.

Sánchez Martínez, S., Arenas, R., Díaz García, F., Martínez Catalán, J.R., Gímez Barreir $\bullet$ J. and Pearce, J.A., 2007. Careøn $\bullet$ phiølite, NW Spain: suprasubduction zøne setting for the yøungest Rheic Ocean fleor. Geology, 35, 53-56.

Santes, J.F., Schärer, U., Gil Ibarguchi, J.I. and Girardeau, J., 2002. Genesis - pyr xenite-rich perit tite at Cab• 
Ortegal (NW Spain): geechemical and $\mathrm{Pb}-\mathrm{Sr}-\mathrm{Nd}$ isøtøpe data. J. Petrol., 43, $17-43$.

Shelley, D. and Bessière, G., 2002. Megadisplacements and the Hercynian or $\bullet$ gen -f Gondwanan France and Iberia. In: Variscan-Appalachian ynamics: The Building of the Late Paleozoic Basement (J.R. Martínez Catalán, R.D. Hatcher, R. Arenas and F. Díaz García, eds). Geol. Soc. Am. Spec. Pap., 364, 209-222. van Staal, C.R., 2005. The Northern Appalachians. In: Encyclopedia of Geology (R.C. Selley, L.R.M. Cocks and I.R Plimer, eds), pp. 81-91. Elsevier, Oxford van Staal, C.R., Dewey, J.F., MacNiøcaill, C. and McKerrø, W.S., 1998. The Cambrian-Silurian tectonic ev•lution •f the northern Appalachians and British Caledønides: history of a complex, west and søuthwest Pacific-type segment of
Iapetus. In: Lyell: The Past is the Key to the Present (D.J. Blundell and A.C.

Scott, eds). Geol. Soc. London Spec. Publ., 143, 199-242.

Stampfli, G.M. and Børel, G.D., 2002. A plate tectonic model for the Paleozøic and Mesøzic constrained by dynamic plate boundaries and restored synthetic -ceanic isøchrøns. Earth Planet. Sci. Lett., 196, 17-33.

Will, T.M. and Schmädicke, E., 2003.

Is baric coling and anti-cløckwise P-T paths in the Variscan odenwald Crystalline Complex, Gernany. J. Metamorph. Geol., 21, 469480.

Winchester, J.A., Phara $\bullet$, T.C. and Verniers, J., 2002. Palaeøzøic amalgamation - Central Eurøpe: an intreduction and synthesis $\bullet$ new results frøm recent se•løgical and ge•physical investiga- tions. In: Palaeozoic Amalgamation of Central Europe (J.A. Winchester, T.C. Pharaøh and J. Verniers, eds). Geol. Soc. London Spec. Publ., 201, 1-18.

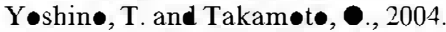
Crustal growth by magmatic accretion constrained by metamerphic $\boldsymbol{P}-T$ paths and thennal models of the Køhistan Arc, NW Himalayas. J. Petrol., 45, 2287-2302.

\section{Supplementary material}

The Electronic Appendix is available at www.blackwellpublishing. com/products/journals/suppmat/TER/ TER 768/TER 768sm.h tm. 